\title{
Research on Application of Universities Ideological and Political Education in New Media Environment
}

\author{
Wang Xiaolin ${ }^{1, a}$ \\ ${ }^{1}$ Hainan College of Software Technology, China \\ awangxiaolin8107@163.com
}

Keywords: Universities, New Media, Ideological and Political Education

\begin{abstract}
With the continuous development and improvement of computer and network technology as the representative of the new media, students use new media with increasing frequency, dramatically changed the lives of students and learning. In the new media have an important impact into the daily lives of students and university students learning and behavior and thinking patterns, new media has brought great convenience to the ideological and political work in universities. Under the influence of the new media environment, ideological and political education not only facing great opportunities, but also faces enormous challenges, the Campus Ideological Educators should fully seize these opportunities and make full use of new media technology good students ideological and political education. The correct treatment of ideological and political education can take effective measures to do a good job of ideological and political education in the new media environment.
\end{abstract}

\section{Theoretical Introduction of New Media Technology}

New media refers mainly relying on Internet technology, digital technology and other tools to disseminate information report form, today's society has gradually towards the development of new social media, computer and network to our lives a lot of influence, the use of computers is already very widespread, especially students, they are more receptive to new things, the Internet for student learning and life provides a great convenience.

From timeliness of information dissemination this point, the new media forms of communication media to break the traditional timing of dissemination, passive acceptance of the law, real-time, real-time, full-time features. The new media play an increasingly important role in this context, many colleges and universities will also ideological and political website, micro-blogging as a tool to carry out under the ideological and political education. However, although the tool carrier has been innovative, but political education theory still lagging behind, in order to allow colleges and universities ideological and political education has been optimized to achieve, both the ideological education and new media on the basis of new media technology college educators should get combination ${ }^{[1]}$.

Analog circuit technology curriculum applies the new project teaching method, which is an electrical circuit effective curriculum teaching reform exploration. Through project teaching, teaching methods reform the traditional theory and practice phase separation, so that students learn by doing, learn to do one, will help improve students' ability to solve practical problems. Analog circuit technology courses project teaching reform of higher education reform in other electrical circuits professional courses there are some inspiration. Implementation of the project will help improve the pedagogy student learning motivation, the ability to solve practical problems, in line with the goal of higher vocational education personnel training. As the new media with strong occult characteristics of students ideological and political education can break the shackles of time and space, teachers and students to achieve equal status in the ideological and political education work. 


\section{Characteristics Analysis of New Media}

In this emphasis on the individual, highlighting the personal values of the times, the new media technology to promote the development of society, and in turn promote the development of social media progress in accordance with its own trajectory, thus shaping the uniqueness of this unique era of new media era ${ }^{[2]}$. Fig.1 shows characteristics analysis of new media.

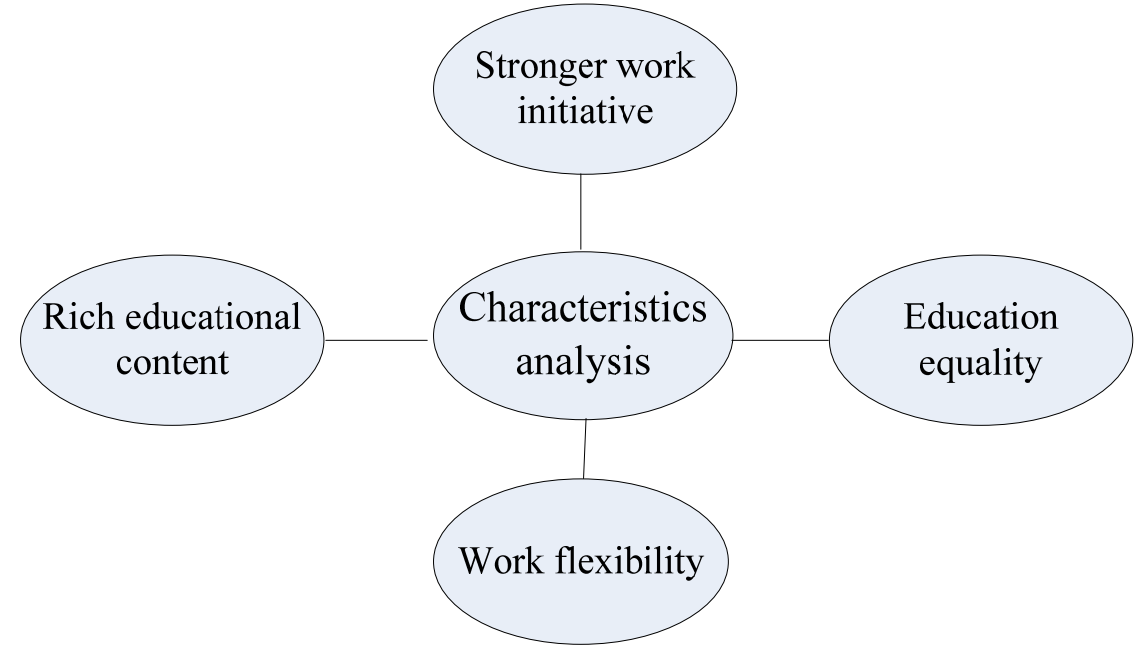

Fig. 1.The characteristics analysis of new media

Compared with traditional means of ideological and political education, the use of new media technologies can provide a richer means of education for the college counselors. Under the new media environment, instructors and students can use various means to communicate, to achieve the ideological and political education of students. Students can go to counselors do not specify the location or place, but simply sitting in front of the computer can accept the ideological and political education to understand the school counselor to convey the spirit and intent of education. The introduction of new media technology for students of ideological and political education, we can create a relaxed environment for the ideological and political education, eliminate barriers between teachers and students identity, eliminating the distance between teachers and students, so that students and teachers have their own ideological and political education on an equal footing feelings.

The use of new media technologies Political Education means more flexibility. The introduction of new media technologies ideological and political education work can be timely and comprehensive grasp the ideological trends of students, and to take timely measures to resolve ideological problems for students. In addition, a wealth of ideological and political education means of increasing the flexibility of political education, ideological and political education of teachers to students to carry out work restrictions of time and place that is less, only to have to be able to communicate with the device. New media and means of education compared to traditional means of education, it is an interactive communicative way of education, so that students get education in the visual feel of the image. To enhance communication and interaction among students and between teachers in this way to build a good communication mechanism to education - feedback - in the form of education to fully mobilize the enthusiasm of students and improve the actual effect of education $^{[3]}$.

\section{Advantages of New Media Applications}

Expand the use of new media for political and ideological education of college students is the main group of teachers, new media, information exchange is not only innovative, but also easy to narrow the gap between teacher and student exchanges. Especially the development of the network, students are accustomed to and like to communicate with the network language, if teachers use students' preferred form of communication conducted political education, and teachers combined 
with years of experience in education and educational means, more easily understood by the students.

New Media has hosted a large, fast, multimedia, high speed, wide coverage and other advantages. In the new media environment, college students access to information not only more convenient, but also began to diversify. Traditional same time, we work on the ideological and political education of college students can also take advantage of the rich resources for multimedia, but also on a larger, more active will quickly pass information to students. The use of new media, teachers can easily get to know the lives of students learning dynamic, plus interest by students learned ideological trends, but also to reach out to the students go. Only by understanding what the students think, be able to make more with less to carry out ideological and political work.

Teachers can use a variety of means to convey information, which compared to the past teaching is more convenient and more flexible. Students do not have to go to a specific place to receive education, the use of new media for information the school may need to pass. New media in favor of the construction of ideological and political education, new media really break the boundaries between the virtual space, making the relationship between students and teachers is more equitable, the use of new media, teachers, students can not only understand the dynamic character through daily student, lifestyle, easier to understand the student's heart, and students will have a better understanding of teachers. Such teachers practice quickly narrow the distance between teachers and students, but also makes it more convenient to carry out ideological and political ${ }^{[4]}$.

\section{New Media Applications for Political Education}

Based on lifting ideological and political education of college students object level, we should fully recognize the importance of new media, traditional media do a good job at the same time, pay attention to the study of new media age of new technologies, new things, and with the traditional media complementary, which can seize the opportunity and actively and properly deal with the challenges. That is, the ideological and political education work of the new media age must be innovative, so the concept of education, educational means and educational support, etc. Students can meet the new era, which continues to take the initiative to lead the ideological and political education, ideological and political education to enhance the level. Fig.2 shows new media applications for ideological and political education.

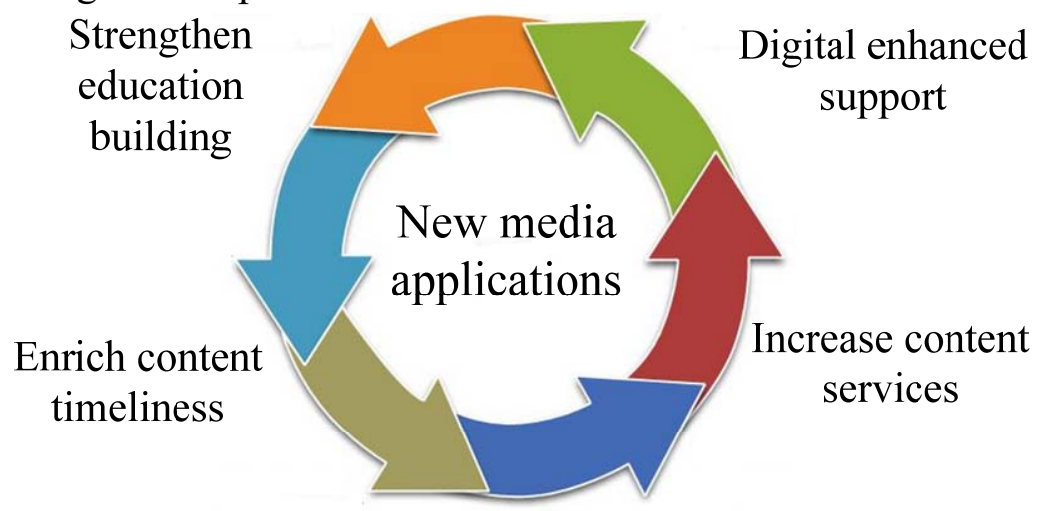

Fig. 2.New media applications for ideological and political education

In the new media age, enhance the level of ideological and political education, both from the theoretical point of view, or from the point of view of social reality, must be content of ideological and political education in the era of binding enrichment. The combination of so-called era of enrichment, originally refers to the ideological and political education system outdated part revision, whenever necessary, thus adding fresh blood, so that the content of education and the trend of the times and is the object of education accepted. New media, traditional media lack interactivity and openness, etc., then the ideological and political education can take advantage of these features to enrich the content level of ideological and political education, thereby enhancing the educational content filters through the layers, thus leading gradually progressive discourse right capabilities. In 
the rapid development of new media today, college students ideological content, values and knowledge sources are becoming more diversified, and this trend at an extremely fast pace. This requires ideological and political education content is constantly accelerating, constantly enrich and thus built up a fresh, rich and diverse educational content ${ }^{[5]}$.

New media age, college students concerned about things diverse, and their ideas and needs also have different levels. Digital technology and new media era of ideological and political education has brought opportunities as well as challenges. In the development of teaching materials, not only to rely on the original single textbook, and to change the form of teaching materials, teaching methods relying on the development of new media in improving the utilization of existing materials, the better use of digital textbooks. Such initiatives not only advancing educational philosophy, but also is an effective way to carry out ideological and political education in the new period.

\section{Conclusions}

With the advancement of technology and the development of society, human beings gradually into the global information age, as a kind of different from the traditional media, new media, new media have been widely used in various areas of society. Students as a relatively special group, new media promptly and fully universal in them, on the ideological and moral quality, daily habits, values, judgment and so formed a certain impact and influence, the traditional ideological and political education It has been difficult to adapt to the requirements of the new era of environment. As a very important means of education, new media technology will play an important role in the ideological and political education. Through effective application of new media, we can take practical and effective measures helping college students' ideological and political education.

\section{References}

[1] Lou Chao. Innovation in the new media environment of ideological and political education [D], Chengdu: Southwest Jiaotong University degree thesis, 2010: 7-32.

[2] Wen Daoqun, Study on enhancing ideological and political education of humanistic care [D], Chongqing: Chongqing Normal University master's thesis, 2011, 2.

[3] Liu Jinglong. Enhanced New Media on Ideological and Political Work Countermeasures [D], Shanghai: East China Normal University, master's degree thesis, 2011, 9.

[4] Hu Xiaoqin. Ideological and Political Education of College Students Study [D], under the new media background Wuhan: Huazhong Normal University degree thesis, 2014, 5.

[5] Lu Xiaohong, Mobile Media Influence and Countermeasures on Ideological and Political Education [D], Shanghai: Shanghai Normal University, degree thesis, 2014, 3. 